\title{
UPAYA MENINGKATAN HASIL BELAJAR MATEMATIKA MELALUI METODE DISKUSI PADA SISWA KELAS VI SD NEGERI 24 INDRALAYA
}

\author{
Nurul Hudah \\ Guru Sekolah Dasar Negeri 24 Indralaya \\ Jalan Palembang Indralaya Kilometer 35 Kecamatan Indralaya \\ Kabupaten Ogan Ilir Sumatera Selatan 30662 \\ Sur-el:nurulhudah65@yahoo.co.id
}

Article info

Article history:

Received: 10/11/2019

Revised : 17/11/2019

Accepted: 19/12/2019

Keywords:

Classroom Action

Research (CAR),

Discussion Methods,

Learning Outcomes,

Mathematics

Kata Kunci:

Penelitian Tindakan

Kelas (PTK), Metode

Diskusi, Hasil

Belajar, Matematika

\begin{abstract}
A B S T R A C T
This study aims to improve student learning outcomes using the method of discussion on math in the $6^{\text {th }}$ grade. The subjects in this study were $6^{\text {th }}$ grade students of SD Negeri 24 Indralaya, totaling 27 students. This research was conducted in semester gazal 2019. The research used Classroom Action Research (CAR). This CAR consists of two cycles. The results showed of 27 students of 74, 07\% achieved completeness of KKM 70 in Cycle 1. In Cycle II, students who achieved KKM 70 increased by $85.19 \%$ with an average grade of 82.59 . So, it can be concluded that learning by using discussion methods can improve student learning outcomes in Mathematics.
\end{abstract}

Penelitian ini bertujuan untuk meningkatkan hasil belajar siswa dengan menggunakan metode diskusi pada pelajaran matematika di kelas VI. Subjek dalam penelitian ini adalah siswa kelas VI SD Negeri 24 Indralaya yang berjumlah 27 orang siswa. Penelitian ini dilaksanakan pada semester ganjil 2019. Penelitian menggunakan Penelitian Tindakan Kelas (PTK). PTK ini terdiri dari dua siklus. Hasil penelitian menunjukkan ketuntasan KKM 70 sebesar 74, 07\% dari 27 siswa pada Siklus I. Pada Siklus II, siswa yang mencapai KKM 70 meningkat sebesar 85,19\% dengan nilai rata-rata kelas sebesar 82,59.Jadi, dapat disimpulkan bahwa pembelajaran dengan menggunakan metode diskusi dapat meningkatkan hasil belajar siswa pada mata pelajaran Matematika.

Direktorat Riset dan Pengabdian Masyarakat Universitas Bina Darma. 


\section{PENDAHULUAN}

Pendidikan adalah salah satu aspek terpenting yang seharusnya menjadi perhatian semua pihak seperti pemerintah, sekolah, guru, orang tua, dan masyarakat umum dalam rangka meningkatkan sumber daya masyarakat Indonesia yang berkualitas. Berdasarkan UU No.20 Tahun 2003 tentang Sistem Pendidikan Nasional, Pendidikan didefinisikan sebagai usaha sadar dan terencana untuk mewujudkan suasana belajar dan proses pembelajaran agar peserta didik secara aktif mengembangkan potensi dirinya untuk memiliki kekuatan spiritual, keagamaan, pengendalian diri, kepribadian, kecerdasan, akhlak mulia, serta keterampilan yang diperlukan dirinya, masyarakat, bangsa, dan negara.

Pendidikan dimulai dari pendidikan dasar yaitu pendidikan Sekolah Dasar (SD) (Hasbullah, 2009). Pendidikan SD merupakan salah satu bentuk satuan pendidikan dasar yang menyelenggarakan program pendidikan enam tahun. Keberhasilan pendidikan dasar sangat berpengaruh untuk melanjutkan jenjang pendidikan berikutnya. Oleh karena itu, proses pembelajaran pada jenjang pendidikan dasar harus dilaksanakan dengan baik. Salah satunya adalah proses pembelajaran berhitung.

Matematika adalah salah satu pelajaran yang penting di sekolah dasar. Mata pelajaran Matematika telah diperkenalkan sejak siswa menginjak kelas I Sekolah Dasar (SD). Secara rinci, Permendiknas No. 22 Tahun2006 tentang Standar Isi untuk mata pelajaran Matematika SD/MI menyatakan bahwa tujuan pembelajaran Matematika di SD adalah (1) melatih cara berpikir dan bernalar dalam menarik kesimpulan, (2) mengembangkan aktivitas kreatif, (3) mengembangkan kemampuan memecahkan masalah, (4) mengembangkan kemampuan menyampaikan informasi atau mengkomunikasikan gagasan. Hal tersebut belum terealisasi pada proses pembelajaran sebenarnya.

Berdasarkan hasil pengamatan awal yang dilakukan oleh penulis di SD Negeri 24 Indralaya diketahui bahwa proses belajar mengajar yang dilakukan oleh guru kelas VI di SD tersebut masih mengunakan metode pembelajaran langsung, yaitu metode ceramah. Proses pembelajaran di kelas tersebut belum mengunakan media pembelajaran yang tepat sesuai dengan kebutuhan belajar siswa dan materi pembelajaran. Metode ceramah yang digunakan oleh guru tersebut mempengaruhi semangat dan antusias siswa dalam mengikuti proses pembelajaran cenderung rendah. Hal tersebut tentu sangat berdampak pada hasil belajar siswa. 


\section{JURNAL ILMIAH \\ BINA EDUKASI \\ ISSN 1979-8598 E-ISSN: 2655-8378 \\ http://journal.binadarma.ac.id/index.php/jurnalbinaedukasi \\ Vol. 12, No. 2, Desember 2019, 42 -- 51}

Diketahui bahwa nilai rata-rata Matematika siswa kelas VI belum mencapai ketuntasan sesuai dengan ketentuan pada Kriteria Ketuntasan Minimal (KKM) yakni 65 dengan target persentase ketuntasan $80 \%$. Berdasarkan nilai prasiklus pada mata pelajaran Matematika di kelas VI diperoleh data, yaitu sebesar 48,15\% atau 13 siswa yang mencapai KKM 65 sedangkan $51,85 \%$ atau 14 siswa belum tuntas. Selain metode pembelajaran yang digunakan, alasan lain peneliti melakukan penelitian ini adalah (1) siswa lebih suka menghafal daripada memahami proses dari suatu materi, (2) minat belajar siswa terhadap mata pelajaran Matematika masih tergolong sangat rendah. Hal tersebutdapat dilihat pada sikap siswa selama mengikuti proses pembelajaran tidak fokus dan ramai sendiri. Oleh karena itu, peneliti melakukan penelitian tentang peningkatan hasil belajar matematika menggunakan metode diskusi.

Adapun penelitian serupa yang pernah dilakukan oleh beberapa orang sebelumnya. Pertama, Itnawati (2016) dengan penelitian berjudul "Metode Diskusi dalam Meningkatkan Hasil Belajar Siswa pada Pembelajaran Matematika di Sekolah Dasar". Hasil penelitian ini menunjukkan bahwa metode diskusi memengaruhi hasil belajar siswa pada mata pelajaran Matematika dengan ketuntasan 75\% pada Siklus I dan II. Kedua, Saadah (2017) dengan judul penelitian "Penerapan Metode Diskusi untuk Meningkatkan Hasil Belajar Matematika pada Materi Menggunakan Pecahan dalam Pemecahan Masalah Siswa Kelas V SDN 003 Tembilahan Kota Kecamatan Tembilahan" dengan hasil penelitian yang menunjukkan bahwa ada peningkatan hasil belajar siswa pada mata pelajaran matematika setalah guru menggunakan metode diskusi dalam kegiatan pembelajaran Matematika. Hal tersebut dilihat dari perbandingan nilai rata-rata pada prasiklus, Siklus I, dan Siklus II, yaitu 55,83 menjadi 80,00 kemudian, pada Siklus II menjadi 88.00 dengan ketuntasan 100\%. Penelitian Tindakan Kelas lain tentang peningkatan hasil belajar menggunakan metode diskusi juga menujukkan hal yang sama. Fatimah (2019) melakukan penelitian tentang "Penerapan Metode Diskusi pada Materi Bangun Ruang untuk Meningkatkan Hasil Belajar Siswa Kelas VI SDN Akkor Palengaan" dengan hasil yang menunjukkan bahwa penerapan metode diskusi pada materi bangun ruang dapat meningkatkan hasil belajar siswa Kelas VI semester II SDN Akkor Kecamatan Palengaan Kabupaten Pamekasan. Hasil tersebut diperoleh dari peningkatan rata-rata hasil tes pada siklus $\mathrm{I}=62$ meningkat menjadi 75 pada siklus II. Sedangkan keaktifan siswa yang semula $43,75 \%$ pada siklus I menjadi $93,75 \%$ pada siklus II.

Berdasarkan uraian latar belakang tersebut maka rumusan masalah penelitian tindakan kelas (PTK) ini adalah "Bagaimana upaya meningkatan hasil belajar Matematika melalui metode diskusi pada siswa kelas VI SD Negeri 24 Indralaya? Penelitian ini diharapkan 
JURNAL ILMIAH

BINA EDUKASI

ISSN 1979-8598 E-ISSN: 2655-8378

http://journal.binadarma.ac.id/index.php/jurnalbinaedukasi

Vol. 12, No. 2, Desember 2019, 42 -- 51

memberikan manfaat bagi siswa dan guru. Siswa diharapkan dapat meningkatkan semangat dan motivasi dalam mengikuti pelajaran Matematika. Guru juga diharapkan dapat berperan sebagai motivator dan dapat lebih berkreasi dalam mendesain metode pembelajaran yang kreatif dan inovatif dalam proses pembelajaran.

\section{METODOLOGI PENELITIAN}

\subsection{Pengertian Hasil Belajar}

Nasution dalam Kunandar (2010), mengatakan bahwa hasil belajar adalah suatu perubahan pada individu yang belajar, tidak hanya mengenai pengetahuan, tetapi juga membentuk kecakapan dan penghayatan dalam pribadi individu yang belajar. Hasil belajar merupakan tujuan akhir yang ingin dicapai setelah mengikuti kegiatan pembelajaran. Hasil belajar adalah sejumlah pengalaman yang diperoleh siswa yang mencakup ranah kognitif, afektif, dan psikomotorik (Rusman, 2013).Dari beberapa teori di atas maka dapat disimpulkan bahwa hasil belajar adalah suatu produk yang dihasilkan dari proses pembelajaran yang berupa pengetahuan kognitif, afektif dan psikomotorik.

\subsection{Pengertian Matematika}

Siswono (dalam Siagian, 2016), mengumpulkan definisi-definisi dari ahli-ahli tahun 1940 - 1970an sebagai berikut: a) matematika sebagai ilmu tentang bilangan dan ruang, b) matematika sebagai ilmu tentang besaran/ kuantitas, c) matematika sebagai ilmu tentang bilangan, ruang, besaran, dan keluasan, d) matematika sebagai ilmu tentang hubungan/relasi, e) matematika sebagai ilmu tentang bentuk yang abstrak, dan f) matematika sebagai ilmu yang bersifat deduktif. Siagian (2016) mengemukakan bahwa matematika merupakan salah satu cabang ilmu pengetahuan yang mempunyai peranan penting dalam perkembangan ilmu pengetahuan dan teknologi, baik sebagai alat bantu dalam penerapan-penerapan bidang ilmu lain maupun dalam pengembangan matematika itu sendiri.Dari pendapat di atas penulis menyimpulkan bahwa pendidikan Matematika adalah ilmu dasar tentang bilangan-bilangan serta hubungan pribadi siswa agar berkembang sesuai dengan perkembangan ilmu dan teknologi.

\subsection{Metode Diskusi}

Metode diskusi dalam proses mengajar dan belajar berarti metode mengemukakan pendapat dalam musyawarah untuk mufakat. Dengan demikian inti dari pengertian diskusi adalah meeting of minds. Metode diskusi adalah cara memecahkan masalah yang dipelajari 


\section{JURNAL ILMIAH \\ BINA EDUKASI \\ ISSN 1979-8598 E-ISSN: 2655-8378 \\ http://journal.binadarma.ac.id/index.php/jurnalbinaedukasi \\ Vol. 12, No. 2, Desember 2019, 42 -- 51}

melalui saling menyampaikan pendapat dalam diskusi kelompok. Menurut Trianto (2015), diskusi merupakan situasi dimana guru dan siswa, atau antar siswa satu dengan siswa lainnya berbincang satu sama lain dan berbagi gagasan dan pendapat mereka selama pembelajaran berlangsung.Dalam pembelajaran, metode diskusi ini memberikan peluang lebih banyak kepada siswa untuk terlibat secara aktif dalam pembelajaran walaupun guru masih menjadi kendali utama.Metodediskusi bertujuan untuk:

(a) melatih peserta didik mengembangkan keterampilan bertanya, berkomunikasi, menafsirkan dan menyimpulkan bahasan;

(b) melatih dan membentuk kestabilan sosio-emosional;

(c) mengembangkan kemampuan berpikir sendiri dalam memecahkan masalah sehingga tumbuh konsep diri yang lebih positif;

(d) mengembangkan keberhasilan peserta didik dalam menemukan pendapat;

(e) mengembangkan sikap terhadap isu-isu kontroversial; dan

(f) melatih peserta didik untuk berpendapat tentang sesuatu masalah.

Aswan (Rahma, 2014) menjelaskan langkah-langkah metode diskusi di sekolah sebagai berikut.

1. Guru mengemukakan masalah yang akan didiskusikan, yaitu berupa soal dari materi pembelajaran yang sedang dipelajari dan memberikan pengarahan mengenai cara pemecahannya.

2. Guru mengarahkan siswa membentuk kelompok-kelompok diskusi, menunjuk ketua diskusi, dan pencatat, mengatur ruangan dan tempat duduk, serta menyediakan sarana.

3. Selama kegiatan berlangsung, guru bertindak sebagai pengamat dan fasilitator bagi siswa.

4. Ketua diskusi berwibawa dan bertindak tegas dalam memimpin kegiatan diskusi, serta memahami masalah diskusi. Setiap anggota kelompok juga harus mengetahui masalah yang akan didiskusikan dan tata cara berdiskusi. Diskusi yang baik memberikan kesempatan kepada setiap anggota untuk menyampikan pendapat.

5. Setelah kegiatan diskusi, setiap kelompok harus melaporkan hasil diskusinya. Laporan diskusi tersebut akan ditanggapi oleh semua siswa dari kelompok lain.

6. Di akhir kegiatan, guru memberi ulasan atau penjelasan terhadap laporan-laporan yang telah didiskusikan oleh masing-masing kelompok. Siswa mencatat hasil diskusi. Guru juga mendokumentasikan laporan hasil diskusi setiap kelompok. 


\subsection{Metode Penelitian}

Penelitian ini merupakan penelitian tindakan kelas (PTK). Penelitian tindakan kelas merupakan suatu perencanaan terhadap kegiatan belajar berupa sebuah tindakan, yang sengaja dimuncullkan dan terjadi dalam sebuah kelas secara bersama (Arikunto, 2012).Prosedur yang dilaksanakan dalam penelitian tindakan kelas ini berbentuk siklus yang akan berlangsung lebih dari satu siklus tergantung dari tingkat keberhasilan dan pencapaian dari target yang akan dicapai. Secara garis besar, dalam setiap siklus terdiri dari empat tahapan yang dilaksanakan yaitu perencanaan, pelaksanaan, observasi (pengalaman) dan refleksi.

\subsection{Tempat, Waktu, dan Subjek Penelitian}

Penelitian ini akan dilaksanakan di SD Negeri 24 Indralaya dikelas VI SD yang berlokasi di Indralaya Kabupaten Ogan Ilir Sumatera Selatan. Pelaksanaan penelitian ini dilaksanakan pada semester gazal tahun 2019 dimulai pada bulan Juli-Oktober 2019.Subjek dalam penelitian ini adalah siswa kelas VI yang berjumlah dua puluh tujuh (27) orang siswa, terdiri dari enam (6) siswa perempuan dan dua puluh satu (21) siswa laki-laki.

\subsection{Teknik Pengumpulan Data}

Dalam kegiatan PTK ini, teknik yang digunakan penulis untuk mengumpulkan data adalah dengan menggunakan tes dan observasi. Data tes yang dikumpulkan adalah data pretes sebelum siklus, dan postes pada Siklus I dan Siklus II. Observasi dilakukan guna mengumpulkan data sekunder sebagai pendukung data tes.

\subsection{Teknik Analisis Data}

Analisis data hasil tes menggunakan rumus yang dimodifikasi dari Aqib (2011), sebagai berikut.

$N a=\frac{\text { jumlah skot yang diperoleh }}{\text { jumlah skor maksimal }} \times 100$

Hasil tersebut digunakan untuk mengetahui data hasil belajar siswa. Nilai rata-rata diperoleh dengan menggunakan rumus berikut. Sedangkan untuk memperoleh nilai rata-rata kelas didapat dengan menggunakan rumus berikut.

$\bar{x}=\frac{\sum X}{\sum N}$

Keterangan:

$\bar{x}=$ Nilai Rata-rata $\quad \sum \mathrm{N}=$ Jumlah Siswa

$\sum \mathrm{X}=$ Jumlah semua nilai siswa 


\section{JURNAL ILMIAH}

BINA EDUKASI

ISSN 1979-8598 E-ISSN: 2655-8378

http://journal.binadarma.ac.id/index.php/jurnalbinaedukasi

Vol. 12, No. 2, Desember 2019, 42 -- 51

Persentase ketuntasan secara klasikal dihitung mengguakan rumus sebagai berikut.

$\mathrm{P}=\frac{\sum \text { siswa yang tuntas belajar }}{\sum \text { siswa }} \times 100 \%$

Kriteria yang digunakan untuk dapat menyimpulkan penelitian ini dikatakan berhasil, yaitu penelitian ini akan dianggap berhasil apabila dalam penelitian ini $80 \%$ dari jumlah siswa, hasil belajar siswa pada mata pelajaran MatematikaKelas VI di SD Negeri 24 Indralaya memenuhi Kriteria Ketuntasan Minimal (KKM) yaitu 70.

\section{HASIL DAN PEMBAHASAN}

Hasil penelitian tersebut berasal dari hasil tes dan hasil pengamatan. Hasil tes disajikan dalam bentuk data kuantitatif sedangkan hasil penelitian nontes berupa hasil observasi disajikan dalam bentuk deskriptif. Penelitian ini bertujuan untuk meningkatkan motivasi dan hasil belajar siswa dengan penerapan metode diskusi. Setiap siswa dituntut untuk mendapatkan hasil yang terbaik dan mampu mengamalkannya dalam kehidupan sehari-hari. Sehingga hasil belajar tidak hilang begitu saja ketika proses pembelajaran selesai, tetapi dapat bertahan dan digunakan ketika diperlukan. Hasil nilai rata-rata pretes prasiklus, postes pada Siklus I dan II dapat dilihat pada gambar berikut.

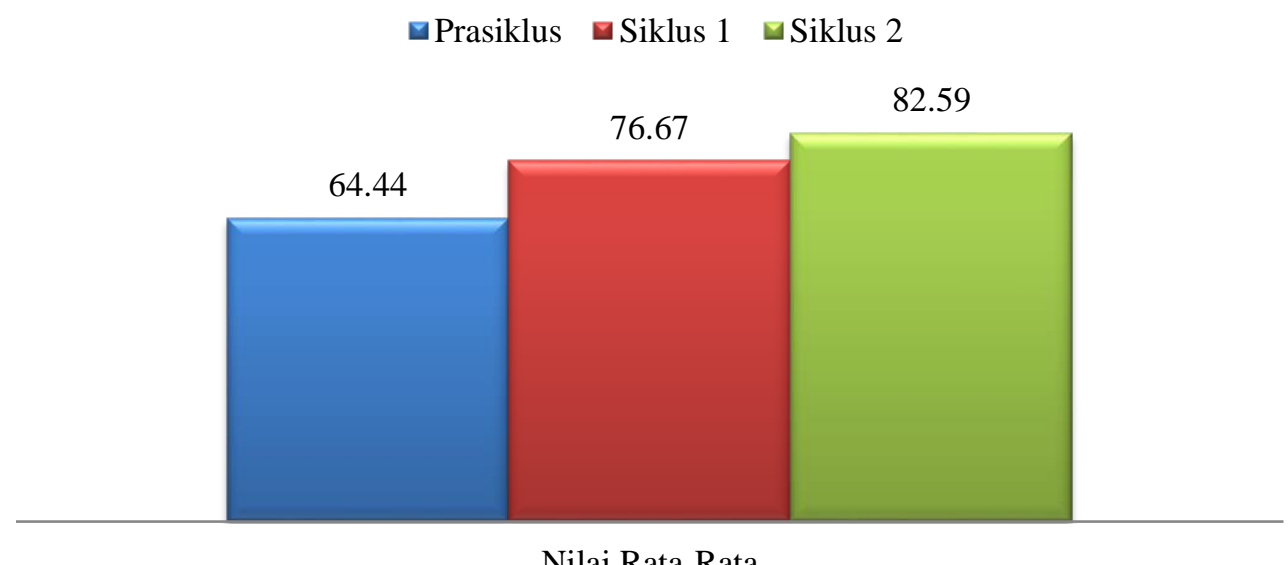

Nilai Rata-Rata

Gambar 1. Nilai Rata-Rata pada Pretes, Postes Siklus I dan II.

Dari keterangan bagan diatas dapat diketahui bahwa hasil belajar siswa Kelas IV SD Negeri 24 Indralaya pada Mata Pelajaran Matematika dapat ditingkatkan dengan penerapan metode diskusi. Pada gambar 1 tersebut terlihat bahwa ada peningkatan nilai rata-rata kelas yang signifikan dari pretes ke postes pada Siklus I, yaitu sebesar $12,23 \%$ yaitu dari $64,44 \%$ meningkat menjadi $76,67 \%$. Keefektifan penerapan metode 


\section{JURNAL ILMIAH \\ BINA EDUKASI \\ ISSN 1979-8598 E-ISSN: 2655-8378 \\ http://journal.binadarma.ac.id/index.php/jurnalbinaedukasi \\ Vol. 12, No. 2, Desember 2019, 42 -- 51}

diskusi dalam peningkatan hasil belajar yang terlihat dari Siklus I ke Siklus II, yaitu 5,92\%. Penelitian ini dicukupkan pada Siklus II karena hasil evaluasi pada siklus kedua sudah mencapai keberhasilan dengan kategori "Cukup Tinggi" dengan persentase siswa yang mencapai nilai KKM 70 sebesar $80 \%$ dan telah mencapai target ketuntasan yang telah ditetapkan.Berdasarkan hasil tersebut berarti hasil penelitian ini sudah mencapai indikator yang ditentukan yaitu $80 \%$ dan peneliti tidak melanjutkan penelitian ke siklus berikutnya. Selain hasil nilai rata-rata, hasil persentase tersebut terlihat pada tabel di bawah ini.

Tabel 1. Persentase Ketuntasan Hasil Belajar Siswa

\begin{tabular}{ccc}
\hline Tahap Tindakan Kelas & Belum Tuntas KKM & Tuntas KKM \\
\hline Prasiklus & 14 Siswa $(51,85 \%)$ & 13 Siswa $(48,15 \%) \%)$ \\
Siklus I & 7 Siswa $(25,93$ & 20 Siswa $(74,07 \%)$ \\
Siklus II & 4 Siswa $(14,81 \%)$ & 23 Siswa $(85,19 \%)$ \\
\hline
\end{tabular}

Dari data tabel tersebut terlihat perbandingan hasil belajar yang signifikan sebelum dan sesudah penerapan metode diskusi dalam pembelajaran Matematika. Persentase ketuntasan meningkat dari prasiklus ke-siklus I sebesar 25,95\%. Kemudian persentase ketuntasan dari postes siklus I ke-siklus II sebesar 11,12\%.

Berdasarkan hasil penelitian, yaitu hasil dari nilai rata-rata pada pretes, kemudian postes di siklus I dan II disimpulkan bahwa penerapan metode diskusi memberikan dampak yang signifikan terhadap hasil belajar siswa. Hal tersebut terlihat dari persentase ketuntasan KKM pada siswa kelas VI dalam pelajaran Matematika. Pada pretes, persentase ketuntasan sebesar $48,15 \%$. Penerapan metode diskusi pada proses pembelajaran Matematika meningkatkan hasil belajar sebesar $37,04 \%$ dari pretes. Peningkatan hasil belajar terjadi karena guru menerapkan metode diskusi.

Berdasarkan hasil observasi pada guru dan siswa terlihat bahwa kegiatan belajar mengajar Matematika menjadi lebih menyenangkan menggunakan metode diskusi. Siswa juga mampu memahami materi dan mampu memecahkan masalah, yaitu persoalan tentang materi pelajaran yang diberikan ole guru. Pada latar belakang, peneliti berharap dengan menerapkan metode ini siswa menjadi lebih antusias dalam pembelajaran Matematika. Penelitian ini juga diharapkan dapat memberikan manfaat pada siswa untuk mampu memecahkan masalah, terutama masalah matematika dalam kehidupan sehari-hari. Hal tersebut sesuai dengan pendapat Suryosubroto (dalam Trianto, 2015) yang mengemukakan bahwa metode diskusi dapat digunakan oleh guru untuk: a) membantu siswa belajar berpikir kritis dan praktis pada berbagai mata pelajaran; b) mengembangkan motivasi untuk belajar lebih lanjut. 


\section{JURNAL ILMIAH}

BINA EDUKASI

ISSN 1979-8598 E-ISSN: 2655-8378

http://journal.binadarma.ac.id/index.php/jurnalbinaedukasi

Vol. 12, No. 2, Desember 2019, 42 -- 51

Dengan demikian, dari penelitian ini menunjukkan bahwa metode diskusi memiliki banyak kelebihan jika diterapkan dalam kegiatan pembelajaran, khususnya pembelajaran Matematika. Adapun kelebihan metode pembelajaran diskusi sebagai berikut.

1) Siswa memahami bahwa banyak cara yang dapat digunakan untuk memecahkan setiap permasalahan. Metode ini dapat mengembangkan pola berpikir siswa meski dengan kemampuan yang berbeda-beda.

2) Siswa terlatih untuk lebih aktif menyampaikan pendapatnya di dalam kelompok maupun kelas. Metode ini mengajarkan siswa untuk percaya diri menyampaikan pendapat dan menghargai pendapat orang lain juga.

3) Siswa belajar bekerja sama dengan kelompoknya dalam menyelesaikan suatu masalah. Metode ini mengembangkan kemampuan interaksi sosial antar siswa.

\section{SIMPULAN}

Berdasarkan hasil penelitian dan pembahasan, dapat disimpulkan bahwa metode diskusi dapat meningkatkan hasil belajar Matematika siswa kelas VI SD Negeri 24 Indralaya Kabupaten Ogan Ilir. Hasil penelitian menunjukkan hasil yang signifikasn dari pretes ke Siklus I dan II, yaitu dari 48,15\% ke-74,07\%, kemudian pada postes Siklus II sebesar 85,19\%. Pada Siklus II, ketuntasan belajar sudah mencapai 80\% maka PTK cukup sampai dengan Siklus II. Selain hasil belajar, penerapan metode diskusi juga meningkatkan motivasi belajar siswa, serta meningkatkan kemampuan siswa dalam berpikir kritis. Pada nilai-nilai karakter, penerapan metode diskusi juga meningkatkan sikap percaya diri, kerja sama, dan menghargai pada siswa.

Hasil penelitian ini diharapkan dapat memberikan pengetahuan dan pengalaman yang berharga bagi peneliti, guru, dan siswa. Peneliti lain juga dapat menerapkan metode ini pada mata pelajaran lain atau materi lain dalam pembelajaran Matematika. Dari penelitian ini, diharapkan guru kreatif dalam mendesain kegiatan belajar dengan menggunakan metode pembelajaran yang sesuai dengan materi dan kebutuhan siswa sehingga pembelajaran menjadi lebih bermakna. Pihak sekolah juga mendukung kegiatan belajar mengajar dengan menyediakan sarana dan prasarana belajar yang layak. 


\section{DAFTAR PUSTAKA}

Aqib, Zainal. dkk. 2011. Penelitian Tindakan Kelas Untuk Guru SD,SLB dan TK.Bandung: Yrama Widya.

Arikunto, Suharsimi. 2012. Dasar-dasar Evaluasi Pendidikan (Edisi Revisi). Jogyakarta: Bumi Aksara.

Badan Standar Nasional. 2006. "Standar Isi untuk Satuan Pendidikan Dasar dan Menengah". (Online). https://bsnp-indonesia.org/id/wp-content/uploads/isi/Permen_22_2006.pdf. Diunduh pada tanggal 16 Oktober 2019.

Diana, Rahma. 2014."Peningkatan Aktivitas dan Hasil Belajar IPA Siswa Kelas V dengan Metode Diskusi pada Sekolah Dasar Negeri 2 Way Kepayang Kedondong Kabupaten Pesawaran TP 2013/2014". http://digilib.unila.ac.id/2866/.Diunduh tanggal 16 Oktober 2019.

Fatimah, Siti. 2019. "Penerapan Metode Diskusi pada Materi Bangun Ruang untuk Meningkatkan Hasil Belajar Siswa Kelas VI SDN Akkor Palengaan”. Jurnal Sigma, 5(2):59—63. http://ejournal.unira.ac.id/index.php/jurnal_sigma/article/view/594/48. Diunduh tanggal 18 Oktober 2019.

Hasbullah. 2009. Dasar-Dasar Ilmu Pendidikan. Jakarta: Rajawali Pers.

Itnawati. 2016. "Metode Diskusi dalam Meningkatkan Hasil Belajar Siswa pada Pembelajaran Matematika di Sekolah Dasar". Suara Guru: Jurnal Pendidikan Sosial, Sains, dan Humaniora, 2(3):277-282. DOI: http://dx.doi.org/10.24014/suara\%20guru.v2i3.2667. Diunduh tanggal 18 Oktober 2019.

Kelembagaan Ristekdikti. 2016. Sistem Pendidikan Nasional. https://kelembagaan.ristekdikti.go.id/wp-content/uploads/2016/08/UU no 20 th 2003. Diunduh tanggal 15 Oktober 2019.

Kunandar. 2010. Langkah Mudah Penelitian Tindakan Kelas sebagai Pengembangan Profesi Guru. Jakarta: PT. Raja Grafindo Persada.

Rusman. 2013. Model - Model Pembelajaran. Jakarta: PT Rajagrafindo Persada.

Saadah. 2017. Penerapan Metode Diskusi untuk Meningkatkan Hasil Belajar Matematika pada Materi Menggunakan Pecahan dalam Pemecahan Masalah Siswa Kelas V SDN 003 Tembilahan Kota Kecamatan Tembilahan". Jurnal Primary Program Studi Pendidikan Guru Sekolah Dasar Fakultas Keguruan dan Ilmu Pendidikan Universitas Riau, 6 (2): 539-545. https://media.neliti.com/media/publications/258265-penerapan-metodediskusi-untuk-meningkat-3904b388.pdf. Diunduh tanggal 15 Oktober 2019.

Siagian, Muhammad Daut. 2016. Kemampuan Koneksi Matematik dalam Pembelajaran Matematika. Journal of Mathematic Education and Science, 2(1): 58-67. Diunduh tanggal 15 Oktober 2019.

Trianto. 2015. Mendesain Mosel Pembelajaran Inovatif Progresif. Jakarta: Kencana. 